\title{
THE DISCOURSE OF NEWS MANAGEMENT
}

\author{
Geert Jacobs, Henk Pander Maat, and Tom Van Hout
}

\section{Introduction}

News scholarship is vast, en vogue and, above all, theoretically eclectic. Case in point is the field of journalism: Recent journals such as Journalism Studies, Journalism Practice and Journalism attest to the interdisciplinary social-scientific interest in news study. Academic interest in journalism has, first and foremost, social causes. As cultural brokers disseminating world knowledge, the stories journalists tell are ideologically significant. This observation is old news, but ever so timely, especially given today's mediascape of convergence, innovation, competition and globalization. Second, even though Zelizer laments that the interdisciplinary debate on journalism lacks a "shared conversational platform" (2004: 3), there is clearly topical and, at times, methodological overlap, what with sociology and anthropology firmly engaged with the ethnographic study of news production. Barring a few notable exceptions (Peterson 2001; Perrin 2006; Cotter forthcoming), however, linguistic accounts of the news have so far missed the ethnographic boat. Indeed, while the rise of ethnography as a research paradigm in professional settings has fostered a sense of rapport between sociology and anthropology, this evolution has gone largely unnoticed in linguistic analyses of news media (for a review, see Cotter 2001).

Media discourse analysis has traditionally focused on the news product. These studies have not only yielded important insights into the structure (Bell 1991, 1998), function (Jaworski, Fitzgerald \& Morris 2003; Khalil 2006) and effect (Fairclough 1995; van Dijk 1998) of media language, they have also described micro level aspects such as the mechanics of turn-taking, repair and pause length in news interviews (Clayman \& Heritage 2002). Recently, however, the scope of media discourse analysis has started to gradually broaden to include the complex discursive practices that lie at the heart of the news production process: If, for example, newspapers are as influential as is often claimed, it must be worthwhile investigating how they are produced, "especially as factors in the process significantly influence - and define - news discourse" (Cotter 2001: 417). In addition, thanks to new technologies, crucial ingredients of the news production process are now being opened up to researchers, with corporate websites parading massive press release archives and internet-based news agencies and e-mail distribution services spreading breaking news in real time to whoever is interested in it.

The linguistic study of press releases came of age with Jacobs' (1999) corpusbased study of preformulation. Observing that the raison d'être of press releases is to be reproduced - preferably verbatim - by the media, Jacobs argued that the "appropriate news style" (Bell 1991: 58) in which press releases are typically written includes the use of powerful, newspaper-like headlines, followed by a comprehensive 'lead' paragraph, 
an inverted pyramid structure and boilerplate as well as a number of special metapragmatic features, most prominently third-person self-reference ('the company' instead of 'we') and (pseudo)quotation ('WP Carey announces today that'). In recent years, this concept of preformulation in press releases has been subjected to further empirical study in corpus and genre analyses (Lenaerts 2002; Lassen 2006; Pander Maat 2007) and also in its institutionalized media and PR setting. Kim Sleurs' research, combining an ethnography of the PR business with the writing process analysis of cognitive psychology, is of particular interest here: Both Sleurs, Jacobs \& Van Waes (2003) and Sleurs \& Jacobs (2005) examine the extent to which preformulation concerns determine how press officers write up their press releases. Similarly, Strobbe \& Jacobs (2005) have examined how the introduction of electronic press releases influences the writing and rewriting routines of news agencies' editorial staff. While preformulation serves as a starting point in most of the contributions to this volume, all of them go beyond it by showing how contextualization and entextualization leads journalists to do a great deal more than just copying what's been cleverly prefabricated for them in a press release. Apart from making a substantial contribution to media discourse studies in this way, the articles in this volume should also be interesting in the way they present a wide range of innovative methodologies exploring contextual practices and entextualization processes, from practice-driven ethnography over genreoriented analysis of move structure to corpus analysis.

It is against this background that we would like to present this special issue on the discourse of what could be called news management. For the first time this volume attempts to bring together various insights from sociology, anthropology and discourse analysis in an attempt to explore processes of news production, in particular those relating to style, genre and intertextuality. As such, we believe that the contributions to this volume will also be of interest to discourse analysts who are not particularly interested in media language. At the same time, we think that the discourse of news management in general and press releases in particular may well constitute one of the few remaining missing links in unravelling the textual mechanics of the media business. The present collection of discourse-oriented articles will then also be relevant to experts from the fields of sociology, cultural studies and anthropology. Painting with broad strokes, the concept of news management is seen here as the triumvirate of news access (source-media interaction), news selection (editorial decision-making) and news production (entextualization). In what follows, we briefly survey relevant research and identify key theoretical concerns before turning to a preview of the articles in this special issue.

\section{News management theory}

News access and news selection are the yin and yang of news production studies. Press releases feature prominently here, with concepts like 'pseudo-events' (Boorstin 1992 [1961]), 'information subsidies’ (Gandy 1982; Vanslyke-Turk 1985) and 'gatekeeping' practices (Shoemaker 1991; Shoemaker, Eichholz, Kim \& Wrigley 2001). Simon Cottle (2000b: 28-9, original emphasis) distinguishes a sociological and a culturalist paradigm in theories of news access. While the former investigates "news access in terms of strategic and definitional power, examining patterns of news access, routines of news production and processes of source intervention", the latter theorizes "news access in 
terms of cultural and ritual power, [sensitive] to the symbolic role of news actors and how they perform/enact within the conventions and textual structures of news representation - ritual, story, narrative".

News sociology has a long-standing tradition: Early, seminal studies of deviance (Becker 1963), newsworthiness (Galtung \& Ruge 1973), news management (Schudson 1978), hegemony and elite access (Hall et al. 1978) paved the way for political economy views of corporate control (Herman \& Chomsky 1988) and mediazation (Thompson 1995) on the one hand, and social constructionist approaches to news production (e.g. Gitlin 1980) on the other. The latter are of particular interest here. Indeed, the classic newsroom ethnographies of the 1970s and 1980s (Tunstall 1971; Tuchman 1972, 1978; Gans 1979; Golding \& Elliot 1979; Fishman 1980; Ericson, Baranek \& Chan 1987) crystallized a radical moment in the historical development of news study. Taken together these studies forced attention to the structural and institutional forces at play in newsrooms, focusing on how news is "an organizational and bureaucratic accomplishment of routine” (Cottle 2000a: 21). For example, Tuchman (1972) sees source dependence as a "strategic ritual", borne out of a professional ideology allowing journalists to frame their work as objective accounts of news events.

While this early generation of social scientists drove home the importance of professional routines, norms, and settings of news production, other scholars have pointed to theoretical blind spots. With new technologies being introduced in newsrooms (Pavlik 2000), come new concepts of journalistic practice (Carlson 2007), leading to questions of continued theoretical validity and calls for updating newsroom ethnography (Cottle 2000a; Zelizer 2004). These calls are only beginning to being answered (cf. Marchetti \& Ruellan 2001; Klinenberg 2005; Machin \& Niblock 2006). In addition, Michael Schudson (2005), has warned against the dangers of a reductionist or determinist approach to the media in which the news production process is seen as the direct result of underlying economic and political forces. Such an approach does not account for the agency of journalists as social actors, which, given today's changing news ecology, is especially pressing. Indeed, it could be argued that, from an analytical point of view, media sociology has largely disregarded journalistic agency in favor of organizational and institutional levels of analysis. Recently, however, some scholars have pointed their attention to alternative theories of cultural production, most prominently, Bourdieu's field theory (Couldry 2003; Benson 2006; Hesmondhalgh 2006; Neveu 2007), which invariably leads us to anthropology.

In contradistinction of grand sociological debates, cultural and anthropological studies of news production such as Peterson (2001) and Ståhlberg (2002) apply notions of social mediation, cultural production and reflexivity in analyzing the situated practices of media production (and consumption). This burgeoning field which has come to be identified as media anthropology (Askew \& Wilk 2002; Ginsburg, AbuLughod \& Larkin 2002; Peterson 2003; Rothenbuhler \& Coman 2005; Boyer \& Hannerz 2006) theorizes the ethnography of media production as "an emergent effort ... to talk about the agency of media producers within a cultural system while still recognizing their embeddedness in larger structures of power" (Peterson 2003: 164). Following a recent trend in anthropology theory toward "mid-level articulations" (Knauft 2006), this line of inquiry promises to give a more balanced account of the social structures and activities involved in news production, which, in turn, is seen as a media practice (Couldry 2004) involving social actors who make interpretive decisions, both socially and textually. Interestingly, "it is out of these interpretive practices that the 
regularities perceived by media sociology as structures, emerge” (Peterson 2001: 201). Crucially, news production becomes a process of entextualization and it is here that a theory of linguistic pragmatics begins to bite. If seen as language-in-use, PR and journalism, can be made analytically sensitive to concepts such as intertextuality (Slembrouck 2002), agency (Ahearn 2001) and genre (Lassen 2006).

\section{Conclusions and overview}

This special issue is the first volume to bring together a wide range of different perspectives on the language of press releases. It is a timely collection, not just because the social relevance of press releases remains as strong as ever, but also because the growing interest in press releases and how they are being produced and reproduced fits in with the rapidly expanding body of work on discourse in institutional settings as well as on the peculiar writing processes, the special participation frameworks and the unique textual features that go with them. Some of the areas that are focused on in this volume include issues of self-reference, pseudo-quotations, promotional language, the use of jargon and structural aspects such as the headline, the lead paragraph, and the boilerplate. Its overall objective is to try and explore some of the institutionalized forces (from PR to journalism) dominating today's newsmaking practices in general and their discursive dimension in particular. The papers in this volume address this issue by investigating the constraints that impact on the writing and rewriting of press releases.

This volume can be subdivided into three parts. The first part draws on genre theory. The second presents ethnographically inspired work on how press releases are being written and rewritten in two different institutional settings. The last two papers propose a corpus analytical approach to the question of what happens to press releases after they have been issued. As such, the volume combines both textual and contextual (even 'entextual') approaches to press releases and this is reflected in the multiplicity of methods that are used: From the macro perspective of communication studies and genre theory, over ethnography, to corpus analysis, all papers presented here can also be seen as pilot studies which explore the strengths and weaknesses of a number of different methodologies for analysing press releases.

Paola Catenaccio examines what she calls the 'hybrid genericity' of press releases. In particular, building on Bhatia's work on the move structure of promotional genres, she identifies a set of typical moves and strategies and links them to the genre's special communicative purposes as well as its unusual participation framework. Catenaccio shows that press releases are a mix of promotion (including advertising) and information (news reporting). But what really turns a press release into a press release, she argues, is the set of peripheral features (the explicit declaration that it is a press release, the company logo, the company description, the contact details) through which it is made manifest to the reader that the text is not just a news report but rather an (in)direct company statement.

Next, Maria Lindholm looks at the practicalities of how press releases are actually being written. She approaches press releases from an ethnographic perspective. Lindholm's work is situated within the context of the European Commission in Brussels, esp. the French and Swedish language communities there. First she tries to examine to what extent press releases issued by the European Commission are different from their counterparts from national ministries. The text features that she identifies, 
viz. structure, voicing and intertextuality, are then ethnographically accounted for with reference to the peculiar communication situation of the European Commission and to the need for the Commission to legitimize its political initiatives. It is clear that power is playing a big role in Lindholm's data, but a different role from what is traditionally thought of in terms of news management discourse.

Following a theoretical discussion of power, interaction and agency in news production, Tom Van Hout \& Geert Jacobs take a behind-the-scenes look at financial newswriting, demonstrating how a news atricle is negotiated in situ between sources (i.c. a press release), a reporter and his editor. This case study follows the genesis of a story, monitoring how it "[bounces] back and forth ... [involving] competitions between parallel intermediary channels of news flow, translations and reinterpretations at different points of the passage, and then final editing before it reaches its audience destination” (Boyer \& Hannerz 2006: 13). What is more, the authors observe the writing process online with keystroke logging and screen recording software.

The final two papers in this volume turn to the question of what happens to press releases after they have been issued. In particular, they set out to shed new light on the actual use of press releases by comparing selected linguistic features in a corpus of press releases with what the journalists have made of them in their own news reporting. In line with Van Hout \& Jacobs's approach - and in contrast with Maria Lindholm's analyses of the writer's end -, these concluding papers focus on the journalists' rewriting end of production process.

Henk Pander Maat, to begin with, starts from a corpus of 50 press releases issued by major industrial companies and then turns to the newspaper reports written about them by economic journalists in daily papers. Based on a detailed transformation analysis, it is shown that readability and not objectivity is the journalists' main concern. The bulk of the editorial work consists not of neutralizing, but of shortening press releases, which sheds new light on the kind of interaction taking place between journalists and their sources. Pander Maat shows that most of the press releases in his corpus turned out to be inadequately preformulated, which seems to raise questions as to whether press release writers are as much preoccupied with preformulation as has been assumed so far.

Frank Jansen too is interested in the way journalists use press releases in their own news reporting. His is a threefold corpus study comparing appositions in press releases ("Hewlett Packard, the world's largest supplier of printers") with those in the news reports based on them. His analysis of appositions is carried out in two directions: He investigates both how appositions in press releases in input copy are dealt with by journalists and what is the source of the appositions in the final news reports. Appositions prove to be a locus of extensive rewriting. Based on both quantitative and qualitative analyses, Jansen concludes that this editing work aims at conciseness, intonational smoothness and a neutral perspective.

Of course, within the limited scope of a brief introduction like this, it is not possible to capture some of the wide range of rich points that are made in the different papers presented here. Still, by way of concluding remark, there are two issues that we would like to touch on. One is that all papers in this volume confirm strongly that news production is a fruitful arena for linguistic pragmatic research, one in which press releases play a leading and highly interesting role. The other has to do with so-called 'preformulation'. So far it has been assumed that one of the main driving forces behind press releases is that they are written in such a way that they can easily be copied by 
journalists in their own reporting. In this volume substantial evidence is provided to demonstrate that preformulation is a real concern, but one that is competing with a number of other both textual and contextual considerations.

\section{References}

Ahearn, Laura M. (2001) Language and Agency. Annual Review of Anthropology 30: 109-137.

Askew, Kelly, and Richard R. Wilk (eds.) (2002) The Anthropology of Media. A Reader. Oxford: Blackwell.

Becker, Howard S. (1963) Outsiders: Studies in the sociology of deviance. New York: The Free Press of Glencoe.

Bell, Allan (1991) The Language of News Media. Oxford: Blackwell.

Bell, Allan (1998) The discourse structure of news stories. In Allan Bell and Peter Garrett (eds.), Approaches to Media Discourse. Oxford: Blackwell, pp. 64-104.

Benson, R. (2006) News media as a "Journalistic field": What Bourdieu adds to new institutionalism, and vice versa. Political Communication 23: 187-202.

Boorstin, Daniel (1992) The Image: A guide to pseudo-events in America. New York: Vintage.

Boyer, Dominic, and Ulf Hannerz (2006) Introduction: Worlds of journalism. Ethnography 7: 5-17.

Carlson, Matt (2007) Blogs and journalistic authority. Journalism Studies 8: 264 - 279.

Clayman, Steven, and John Heritage (2002) The News Interview: Journalists and Public Figures on the Air. Cambridge: Cambridge University Press.

Cotter, Colleen (2001) Discourse and Media. In D. Schiffrin, D. Tannen and H.E. Hamilton (eds.), The Handbook of Discourse Analysis. Oxford: Blackwell, pp. 416-436.

Cotter, Colleen (forthcoming) Shaping the Language of News: The Practice and Process of Everyday Journalism.

Cottle, Simon (2000a) New(s) Times: Towards a "Second Wave” of news ethnography. Communications: The European Journal of Communication Research 25: 19-41.

Cottle, Simon (2000b) Rethinking news access. Journalism Studies 1: 427 - 448.

Couldry, Nick (2003) Media meta-capital: Extending the range of Bourdieu's field theory. Theory and Society 32: 653-677.

Couldry, Nick (2004) Theorising media as practice. Social Semiotics 14: 115 - 132.

Ericson, R.V., P.M. Baranek, and J.B.L. Chan (1987) Visualizing Deviance: A Study of News Organisation. Toronto: Toronto University Press.

Fairclough, Norman (1995) Media Discourse. London: Edward Arnold.

Fishman, M. (1980) Manufacturing the News. Austin: Texas University Press. 
Galtung, J., and M. Ruge (1973) Structuring and selecting the news. In S. Cohen and J. Young (eds.), The manufacture of news London: Constable.

Gandy, Oscar H. (1982) Beyond Agenda Setting: Information Subsidies and Public Policy. Norwood, NJ: Ablex Publishing.

Gans, H.J. (1979) Deciding What's News. A Study of CBS Evening News, NBC Nightly News, Newsweek, and Time. New York: Pantheon.

Ginsburg, Faye, Lila Abu-Lughod, and Brian Larkin (eds.) (2002) Media Worlds: Anthropology on New Terrain. Berkeley: University of California Press.

Gitlin, Todd (1980) The Whole World is Watching: Mass media in the making and unmaking of the new left. Berkeley: University of California Press.

Golding, P., and P. Elliot (1979) Making the news. London: Longman.

Hall, Stuart, C. Chritcher, T. Jefferson, J. Clarke, and B. Roberts (1978) Policing the Crisis. Mugging, the State and Law and Order. London: Macmillan.

Herman, E.S., and Noam Chomsky (1988) Manufacturing Consent. New York: Pantheon.

Hesmondhalgh, D. (2006) Bourdieu, the media and cultural production. Media Culture \& Society 28: 211-231.

Jacobs, Geert (1999) Preformulating the news. An analysis of the metapragmatics of press releases. Amsterdam: John Benjamins Publishing Company..

Jaworski, Adam, Richard Fitzgerald, and Debbie Morris (2003) Certainty and speculation in news reporting of the future: The execution of Timothy McVeigh. Discourse Studies 5: 33-49.

Khalil, Esam N. (2006) Communicating affect in news stories: The case of the lead sentence. Text \& Talk 26: 329-349.

Klinenberg, E. (2005) Convergence: News production in a digital age. Annals of the American Academy of Political and Social Science 597: 48-64.

Knauft, Bruce M. (2006) Anthropology in the middle. Anthropological Theory 6: 407-430.

Lassen, Inger (2006) Is the press release a genre? A study of form and content. Discourse Studies 8: 503530.

Lenaerts, Gilberte (2002) In pursuit of the functional quality of political press releases. Document Design 3: 210-223.

Machin, David, and Sarah Niblock (2006) News production: Theory and practice. London: Routledge.

Marchetti, Dominique, and Denis Ruellan (2001) Devenir journalistes. Sociologie de l'entrée dans le marché du travail. Paris: Documentation française.

Neveu, Erik (2007) Pierre Bourdieu. Journalism Studies 8: 335 - 347.

Pander Maat, Henk (2007). How promotional language in press releases is dealt with by journalists. Genre mixing or genre conflict? Journal of Business Communication 44: 59-95.

Pavlik, J. (2000) The Impact of Technology on Journalism. Journalism Studies 1: 229-237.

Perrin, Daniel (2006) Medienlinguistik. Konstanz: UVK. 
Peterson, Mark Allen (2001) Getting to the story: Unwriteable discourse and interpretive practice in American journalism. Anthropological Quarterly 74: 201-211.

Peterson, Mark Allen (2003) Anthropology \& Mass Communication. Media and myth in the new millenium. New York: Berghahn Books.

Rothenbuhler, Eric W., and Mihai Coman (eds.) (2005) Media Anthropology. Thousand Oaks: Sage.

Schudson, Michael (1978) Discovering the News: A social history of American newspapers. New York Basic Books.

Schudson, Michael (2005) Autonomy from What? In R. Benson and E. Neveu (eds.), Bourdieu and the Journalistic Field. Cambridge: Polity, pp. 214-223.

Shoemaker, Pamela J. (1991) Communication concepts 3: Gatekeeping. Newbury Park, CA: Sage.

Shoemaker, Pamela J., Martin Eichholz, Eunyi Kim, and Brenda Wrigley (2001) Individual and Routine Forces in Gatekeeping. Journalism and Mass Communications Quarterly 78: 233-246.

Slembrouck, S. (2002) Intertextuality. In Jef Verschueren, Jan-Ola Östman, Jan Blommaert and Chris Bulcaen (eds.), Handbook of Pragmatics Amsterdam: Benjamins Publishing Company.

Sleurs, K., and G. Jacobs (2005) Beyond preformulation: An ethnographic perspective on press releases. Journal of Pragmatics 37: 1251-1273.

Sleurs, K., G. Jacobs, and L. Van Waes (2003) Constructing press releases, constructing quotations: A case study. Journal of Sociolinguistics 7: 192-212.

Ståhlberg, Per (2002) Lucknow Daily: How a Hindi Newspaper Constructs Reality. Stockholm: Stockholm Studies in Social Anthropology.

Strobbe, Ilse, and G. Jacobs (2005) E-releases: A view from linguistic pragmatics. Public Relations Review 31: 289-291.

Thompson, John (1995) The Media and Modernity. A Social Theory of the Media. Cambrige: Polity.

Tuchman, Gaye (1972) Objectivity as strategic ritual: An examination of newsmen's notions of objectivity. American Journal of Sociology 77: 660-79.

Tuchman, Gaye (1978) Making news: A study in the construction of reality. New York: MacMillan.

Tunstall, J. (ed.) (1971) Journalists at Work. London: Constable.

van Dijk, Teun A. (1998) Opinions and ideologies in the press. In Allan Bell and Peter Garrett (eds.), Approaches to Media Discourse. Oxford: Blackwell, pp. 21-63.

Vanslyke-Turk, Judy (1985) Information subsidies and influence. Public Relations Review 11: 10-25.

Zelizer, Barbie (2004) Taking Journalism Seriously: News and the Academy. Thousand Oaks: Sage. 